\title{
THE POLITICAL-ECONOMY MANAGEMENT: INDONESIA'S NEEDS FOR THE COVID-19 PANDEMIC
}

\author{
Jiuhardi Jiuhardi \\ Mulawarman University, Indonesia \\ E-mail: jiuhardi@feb.unmul.ac.id \\ Dio Caisar Darma \\ Samarinda High College of Economics, Indonesia \\ E-mail: diocaisar@stiesam.ac.id \\ Ariesta Heksarini \\ Mulawarman University, Indonesia \\ E-mail: ariesta.heksarini@feb.unmul.ac.id
}

\begin{abstract}
The Covid-19 outbreak continues to spread rapidly to almost all countries in the world. The authors need to highlight how the policy perspectives are taken by Indonesia at the national scale and international relations to improve the economic and political situation during this pandemic. Referring to this phenomenon, this research provides an in-depth study of the literature review on strategic efforts and steps to address commodity demand in Indonesia. In short, from an economic and political point of view, the dual problems on the supply and demand side make the premise of comparative advantage (which is the foundation of a free-market economy and international trade) into doubt about its validity. The classical premise argues that social welfare will be optimal if the state specializes in producing goods which are. Having the lowest opportunity cost according to the availability of production factors and buying other needs in the international market, it seems only valid if the international trade mechanism is not disrupted. Conversely, in conditions of supply and demand shocks, all countries will try to produce all their needs domestically and limit exporting products abroad as much as possible.
\end{abstract}

Key words: national trade, global markets, export policy, import policy, Covid-19

\section{Introduction}

Corona Virus Disease 2019 (Covid-19) is now a disease that is infecting almost the entire population of the world community. This disease is caused by a new virus that can cause serious infections like Covid-19 in general such as Acute Respiratory Syndrome (SARS) caused by SARS-Cov in 2002, and Middle East Respiratory Syndrome (MERS) caused by MERS-Cov in 2012 (for example Ilmi et al., 2020b).

In mid-March 2020, WHO (2020) finally declared that Covid-19 was a global pandemic for which there was no cure to completely stop the virus until now. When viewed and examined, there are two aspects that are highly highlighted by this virus, namely aspects of public policy and the political economy of a country. This pandemic actually did not just appear because in 1918-1919 there was also a deadly virus, namely the Spanish flu. The plague was deadly and became a pandemic and claimed 40 million lives. However, the re-emergence of this deadly Covid-19 is far more virulent than its predecessor virus. Effendi (2020) informs that 
Jiuhardi JIUHARDI, Dio CAISAR DARMA, Ariesta HEKSARINI. The political-economy management: Indonesia's needs for the Covid-19 pandemic

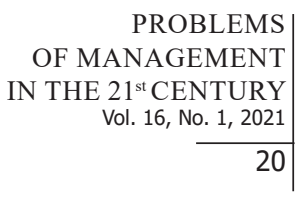

20

the total number of Covid-19 sufferers has reached more than 5.5 million people so far with recovery and death rates of $40.91 \%$ and $6.26 \%$ respectively. In Indonesia, the massive Covid- 19 contamination rate is still ongoing in various regions with a total of 23,165 cases with a death rate of $6.12 \%$ or at least slightly lower than the global mortality rate.

Darma et al. (2020a) reveal that in addition to creating a global health crisis, suppression efforts, and mitigating a pandemic, Covid-19 has also caused a strong disruption to the international trade order. From the supply side, the lockdown policy and working from home resulted in a reduction in workers involved in production activities.

\section{Research Problem}

The Covid-19 pandemic has the potential to change the world's economic order, which is marked by a change in the world trade map, in addition to stagnating various business fields. It is certain that global trade performance will be disrupted due to the slow improvement in manufacturing performance, particularly in China until the first half of 2020. In the last 5 years, China has always been in the top three of Indonesia's main trading partners. Since 2014, China has been the country of origin for imports with the greatest value for Indonesia. Based on the categories of consumer goods, raw materials, and capital goods from January to December 2019 , it is increasingly clear Indonesia's dependence on China. Of the three categories of goods imported by this country, $37 \%$ of consumer goods, $25 \%$ of supporting raw materials, and $44 \%$ of capital goods are clearly imported from China. In terms of direct investment, during the last 5 years (2016-2019), Indonesia received a flow of Chinese investment of US \$ 13.2 billion or the third largest for Indonesia. Apart from investing, China also has a big role in the tourism sector in Indonesia. In a period of 8 years, Chinese tourists increased by 309\%, from 511,000 in 2010 to 2.14 million in 2017 (Supriyanto, 2020; BPS-Statistics of Indonesia, 2020).

The IMF (2020) now predicts world economic output will shrink by nearly $5 \%$ this year, or nearly $2 \%$ worse than the forecast released in April. With this recession, the world will lose economic output worth US $\$ 12$ trillion over two years. China is the only major country that is expected to continue to post growth even though it is only $1 \%$ this year. Meanwhile, a number of Western European countries (including Britain and France), are expected to experience shrinkage of more than $10 \%$.

\section{Research Focus}

This research analyzed the Covid-19 phenomenon from the perspective of national policy and international relations pursued by Indonesia, particularly in the economic domain and in brief, from an economic and political perspective, that international phenomena occur as a consequence of the interaction between the power of the state (politics) and companies (markets) at the global level (Mursitama, 2020). In this interaction, each actor has its own interests to be achieved. In the end, it gives birth to who will be the winner and who must be willing to be the loser. Because of this interaction, basically involving the community, the consequences of the interaction of the two forces also have an impact on civil society at the national level (domestic in a country) and locally.

The spread of this global epidemic also has not only an extreme impact on export and import problems because most companies and factories are weakened by an operating system that is not functioning normally but also contributes to weakening the economy in Indonesia. This is certainly a boomerang against other countries, especially for ASEAN. The supply tends to be unstable, has a derivative effect on spikes in food prices. Likewise, with the limited space for movement, a large reduction in production inputs, the welfare of the community has dropped dramatically, and of course, the number of unemployed has increased sharply (Rusiadi et al., 
2020). Over time, economic instability and inflation rates cannot be ascertained for a long time.

This research concentrates on the Indonesian government's policy to consider long-term aspects at the national and international levels so that the decisions taken can stimulate economic recovery. The first part is an introduction to the background of the phenomena surrounding the objectivity of the study, the main problems, and the focus of the study. In the second part, a brief summary of the concepts in the method. From the third part, synthesis analysis and discussions regarding the main objectives of the study are to review the national policies and international policies that Indonesia should strive to reflect on the politics and economy so that chaos does not occur during Covid-19. Finally, in the fourth section, to be precise, there are references that support this study.

\section{Research Methodology}

This study was set up through an in-depth literature approach. This technique is a series of activities related to reading, taking notes, collecting library data, and managing materials tailored to the needs of the study. Maria et al. (2020) and Karatzoglou (2013) have ensured that literature studies are recommended to researchers who have a broader in-depth digging in more detail with regard to the problem being observed. The pilot project in this study also ensures and adjusts the problems surrounding the management of the Indonesian government through policies, so that there needs to be a discussion of the impact caused by Covid-19 with the right political and economic steps.

\section{Research Results}

\section{Political-economy Affected by Covid-19}

The economic activity of a country is highly highlighted in the midst of this global pandemic. It is not impossible that a political economy activity requires a conducive situation to maintain its positive economic trend. The supply of the flow of goods and services is at stake if the countries affected by Corona take a protectionist policy stance, which means that a country cannot carry out trade activities carelessly. Of the several policies of a country, the policy trend that is most taken is the lockdown policy (regional quarantine). Lockdown is a public policy package that aims to secure the country against a threat (Ibrahim, 2020).

This policy is accompanied by assistance from the government, such as the availability of foodstuffs, health, and others (e.g., Kovács \& Nyerki, 2015). All of these things are a form of government responsibility to the people who are being isolated. The efforts made by developed and developing countries in implementing lockdowns are in fact not yet effective and are working quite well. This can be seen from the declining trend of the global market and economy, of course, the losses from all of them have not been able to calculate the exact figure until now.

The monetary, fiscal, and structural sectors have completely collapsed due to the Covid-19 pandemic. No kidding, apart from having a social impact (social and physical distancing), this epidemic also had an impact on the political economy. Several countries, including China, are experiencing serious trade balance deficits. In the first quarter of 2020, China must be willing to experience an import-export deficit of $17.2 \%$. What happened in that country did not include the calculation of the advantages and disadvantages of several other aspects. This fact is a partial picture of the state of a country like China. Countries such as Italy, France, Poland, Denmark, El Salvador, and Belgium have imposed lockdown since March.

High risks were taken, from economic recession to collapse in the financial sector. The worst risk is the riots that occur in India between the lockdown in the country with the largest 
Jiuhardi JIUHARDI, Dio CAISAR DARMA, Ariesta HEKSARINI. The political-economy management: Indonesia's needs for the Covid-19 pandemic

OF MANAGEMENT IN THE $21^{\text {st }}$ CENTURY Vol. 16, No. 1, 2021

Hindu population. With many countries taking lockdown policy steps to overcome Covid-19, this will practically shackle all forms of international trade (flow of goods and services) in the spectrum of the political economy.

\section{Country versus Market}

The outbreak of Covid-19 around the world has become a global pandemic forcing the world to change. Not only from the country, the market, but also from the community. At least until now, China is considered as one example of a country that has succeeded in reducing this epidemic and has reached out to help Italy. Meanwhile, several other countries followed with policies that varied from lock-down starting from a certain period to close some of their territories (Darma et al., 2020b).

As the only authority that is given legal authority by statutory law to use force to force control of its citizens with weapons (military and police), the state can exercise its power and politics. For this reason, some countries have closed their entire territory (lockdown), limited territorial quarantine, and have limited the movement of their citizens with the assistance of the police and even the military.

The state can impose penalties for violators. The state must be present to maintain order and keep the situation safe and the people calm. The community feels safe and comfortable and is not overwhelmed by fear, including access to daily needs. For example, ensuring that residents do not starve, maintaining access to information from the government in a transparent manner, and access to health facilities if anyone is affected by the symptoms of Covid-19 (Marrone \& Finotto, 2020).

In this context, the state sometimes collides with the interests of companies (big and small businesses). Market logic is to make as much profit as possible in order to get prosperity. The company certainly tries to keep operating at least to reduce losses. The people can imagine if access to the international world as well as from outside to the country is completely closed, business activities will stop. The endpoint is not only on the continuity of the business itself but also on workers who do not get a salary.

The impact of business non-operation is mixed. White-collared employees may still be able to get their rights in the form of a salary or bonus. At worst, they will experience a slight cut or delay in bonus payments. For large companies, especially multi-national companies with large assets and turnover, it may not be a big problem.

For the upper-class workers, whose lives depend on whether they work or not that day, it can be a small doomsday. If they do not work, they do not get paid. This means that they cannot meet the needs of their daily lives. This is a very real problem. For medium-sized companies with assets and turnover that are not too large and rely on medium or short-term cash flow, this can be a time bomb, especially for small businesses whose lives depend on daily transactions.

\section{Looking for Equilibrium}

In a situation like today, who are the winners and losers, the country or the market cannot be answered simply. If the state puts forward the situation of the security and public order for citizens to be controlled and remain calm, and the spread of the virus can be limited by largescale social restrictions or even a total lockdown, even if there is an alternative to a civil or military emergency, all have consequences.

Say that the country becomes the winner by deciding to choose one of the alternatives above, it must have considered the advantages and disadvantages. First, business activity is likely to be paralyzed. From large to small scale, there must be potential downsides. The state needs to intervene by identifying the companies or community groups that will suffer losses from the 
greatest to the least. Then, the State can provide incentives for the continuity of their business. For example, tax relief, debt installments, direct assistance in the form of cash or not, providing

PROBLEMS

OF MANAGEMENT

IN THE $21^{\text {st }}$ CENTURY

Vol. 16 , No. 1, 2021 certain subsidies with other stimulus packages according to industry and segmentation. Second, companies in the medical equipment and pharmaceutical industries can continue to contribute by making personal protective equipment, vitamins, medicines, and others needed.

Companies in certain industries that have the technology or business processes maybe diverted to make products that can be used to deal with the outbreak of the Covid-19 virus. Industries that produce staple foods can continue to operate on a limited basis and or use technological assistance. Companies like this at the same time practice being socially responsible for their consumers and the environment, not only as companies whose main objective is to only make big profits. If this can happen, then it is proof that companies can also contribute to the current emergency situation (Chesta et al., 2020).

At this point, there has actually been a new balance in the form of opportunities for cooperation between the state and the market. When needed, the state is present to guarantee the safety, order, and security of its citizens on the one hand, but also provide space for the market to continue to contribute. Of course, it takes a series of concrete steps to implement it. But most importantly, the price of human life is far more than any business advantage, even political position at any level. Currently, this is an emergency, emergency, and extraordinary condition beyond human control so that we should deal with extraordinary policies. Not only long debates about formal legal aspects alone, material losses to businesses, interests of certain groups, or politics, let alone individuals. We need fast certainty, considering that whatever decisions that will be taken have consequences before it is too late, and the losses to society will be even greater.

\section{Trade Disruption}

Transportation policies require the government to close water and airports which hinder the distribution of goods between countries. Saubani (2020) reports a decrease in the quantity of international cargo transportation (belly-hold and freighters) until March 2020 by $23 \%$ on a year-on-year basis with an estimated loss of US \$ 1.6 billion.

Furthermore, the country's decision to impose export restrictions in order to protect domestic supplies also adds to the complexity of the problem. The WTO (2020) notes that 80 countries and customs authorities have implemented export restrictions on medical equipment, foodstuffs, and toilet paper including countries that have become world food 'granaries' such as Russia, Vietnam, and Argentina. From the demand side, changes in consumer preferences due to Covid-19 have caused a mismatch between supply and demand. For food, for example, a recent study from the FAO (2020) found an increase in consumer interest in food products that have a shell or skin and are tightly packed. In fact, consumers in some countries are not reluctant to refuse food products originating from China. In addition, the lockdown policy requires the government to close traditional markets, thereby limiting consumer access to food which results in increased food waste. 
Jiuhardi JIUHARDI, Dio CAISAR DARMA, Ariesta HEKSARINI. The political-economy management: Indonesia's needs for the Covid-19 pandemic

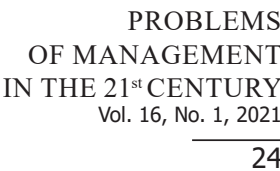

Figure 1

Indonesia's Exports, Imports, and Trade Balance in May, 2020

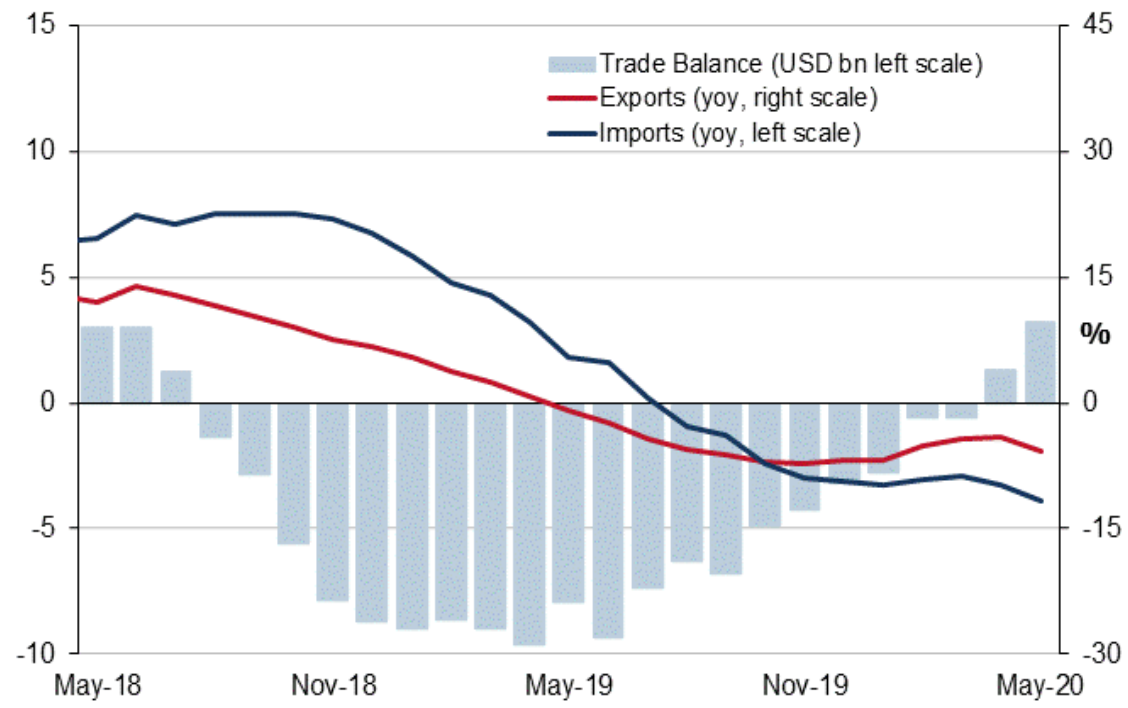

Source: BPS-Statistics of Indonesia (2020).

Some developing countries have even adopted the concept of 'Food Sovereignty and Solidarity' which gives constitutional rights to the people to determine the best food production and consumption options including the application of an agricultural system that is in accordance with local resources and wisdom. In this concept, food products are placed as part of human solidarity so that they are free from all provisions of the market economy and international trade. Indonesia has adopted the concept of food sovereignty through the Law of the Republic of Indonesia Number 18 of 2012 concerning food, but it has not been implemented holistically. The disruption of international trade has also made government efforts to maintain people's purchasing power during recessions problematic. It must be admitted that Indonesia is still very dependent on imports to meet essential needs during a pandemic such as food, energy, medicine, and health equipment.

BPS-Statistics of Indonesia recorded that the total imports of oil, rice, wheat, meat, and soybeans in May-2020 reached 40,926 tons, 444,000 tons, 10,692 tons, 262,000 tons, and 2,670 tons, respectively. Figure 1 presented the scarcity of essential goods in the domestic market due to the disruption of imports, which would certainly trigger supply-push inflation that hit people's purchasing power. In fact, if it continues, this problem can lead to social conflicts that make the "costs" of handling a pandemic even higher. Therefore, the government needs to immediately take strategic steps to minimize the impact of the trade disruption while preventing the health crisis from developing into a food crisis.

Several attempts can be made. First, increasing the productivity of the domestic agricultural sector by intensifying the production process and increasing economic stimulus for industry and farmer groups. Second, minimizing disruption in the domestic supply chain by utilizing information and communication technology. The government, through cooperation with e-commerce service providers, can transform the food price reference system belonging to the Ministry of Agriculture and the information system for Village-Owned Enterprises owned by the Ministry of Villages and Disadvantaged Regions into an integrated food marketplace that brings together producers and consumers at the best prices. Third, optimize the role of 
food banks (Perum Bulog and regional government-owned cooperatives) to carry out the functions of food supply management, price stabilization, and distribution. Fourth, relaxing

PROBLEMS

OF MANAGEMENT

IN THE $21^{\text {st }}$ CENTURY

Vol. 16 , No. 1, 2021 import duty levies and non-tariff barriers (quotas and import approvals) for essential products. Fifth, affirming the commitment of trading partners in the region, especially food-producing countries, such as Australia, Thailand, Vietnam, and Myanmar to continue to provide market access and not make export restrictions.

\section{Conclusions}

Indonesia is known as a country with beautiful tourist spots until one day when the Covid-19 pandemic entered Indonesia and the government did not take the problem seriously. In this case, it seems that the government is judged and seen as afraid to make decisions, even though state institutions have the authority to determine the direction of policies that uphold the principles of humanity and welfare. The government has many options for determining public policies that are considered to be able to save the people, which focuses on the smallest (micro) social order, with local lockdown efforts or the lockdown of some areas that have the most impact on Covid-19. This is done as a condition of humanitarian investment. If you consider a policy only from an economic point of view, it is of course detrimental. Because material losses have a very real effect, if this is taken, the most appropriate step is to provide support in the form of capital stimulus to companies or activists of Micro, Small, and Medium Enterprises (MSMEs) who will be affected by the policy later.

In the same situation, the government is asked to be firm and reduce jokes which can eventually lead to new problems in the midst of the problems this nation is facing. Perhaps this is the time for the leaders of this country to learn how and why it is important to understand public psychology so that everything they say can be filtered first to reduce public panic.

In order to stimulate the economy, globally coordinated programs will be more effective in overcoming this global depression than acting alone, especially with regard to fiscal policy. When a country cuts taxes and provides emergency financial assistance to households that really need it, an increase in domestic demand will spur global demand through additional imports. Thus, the awareness of each party (private, government, and civil society) is needed to comply with the various policies implemented in order to break the chain of the spread of covid-19, so that the economy is not depressed, and economic growth begins to increase.

\section{Acknowledgements}

Each author has contributed to compiling this article. D.C.D is a corresponding author for generating ideas based on currently relevant topics, designing concepts, and making models in the discussion. J.J and A.H describe the problems and phenomena related to the topic, then expose them to the study model, and look for references from reputable journals, websites, and various books in relation to article needs.

\section{References}

BPS-Statistics of Indonesia. (2020). Indonesia Trade Balance May 2020. Exports and imports plummet in May, trade balance moves to surplus. https:/www.focus-economics.com/countries/indonesia/ news/trade-balance/exports-and-imports-plummet-in-may-trade-balance-moves-to

Chesta, R. E., Zamponi, L., \& Caciagli, C. (2020). Labour activism and social movement unionism in the gig economy: Food delivery workers struggle in Italy. Partecipazione e Conflitto, 12(3), 819-844.

Darma, D. C., Ilmi, Z., Darma, S., \& Syaharuddin, Y. (2020). Covid-19 and its impact on education: Challenges from Industry 4.0. Aquademia, 4(2), Article ep20025. https://doi.org/10.29333/aquademia/8453 
Jiuhardi JIUHARDI, Dio CAISAR DARMA, Ariesta HEKSARINI. The political-economy management: Indonesia's needs for the Covid-19 pandemic

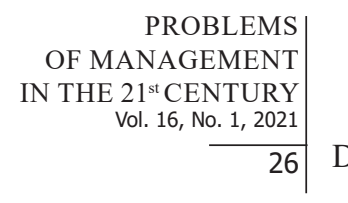

Darma, S., Wijaya, A., \& Darma, D. C. (2020a). Different tests for the existence of agricultural cooperatives in Indonesia: Before and after Covid-19. Asia Life Sciences, 10(3), 615-628. https:// www.academicspub.com/article/different-tests-for-the-existence-of-agricultural-cooperatives-inindonesia-before-and-after-covid-19

Darma, S., Pusriadi, T., Yijo, S., \& Darma, D. C. (2020b). Indonesia government's strategy for food security: During the Covid-19 period. International Journal of Advanced Science and Technology, 29(4), 10338-10348. http://sersc.org/journals/index.php/IJAST/article/view/33070

Effendi, S. (2020). Pandemi dan disrupsi perdagangan internasional [Pandemic and international trade disruption]. In-Depth. https://katadata.co.id/redaksi/indepth/5ed1ef9a32fe9/pandemi-dandisrupsi-perdagangan-internasional

Ibrahim, M. M. (2020). Antara corona, ekonomi politik, dan dagelan [Between corona, political economy, and joke]. Ruang Publik. https://pinterpolitik.com/antara-corona-ekonomi-politik-dan-dagelan

Ilmi, Z., Darma, D. C., \& Azis, M. (2020a). Independence in learning, education management, and industry 4.0: Habitat Indonesia during Covid-19. Journal of Anthropology of Sport and Physical Education, 4(4), 63-66. https://doi.org/10.26773/jaspe.201010

Ilmi, Z., Wijaya, A., Kasuma, J., \& Darma, D. C. (2020b). The crowdsourcing data for innovation: Does it matter? European Journal of Management Issues, 28(1-2), 3-12. https://doi.org/10.15421/192001

Karatzoglou, B. (2013). An in-depth literature review of the evolving roles and contributions of universities to education for sustainable development. Journal of Cleaner Production, 49, 4453. https://doi.org/10.1016/j.jclepro.2012.07.043

Kovács, Z., \& Nyerki, E. (2015). Effect of political change to the change of corporate values. Problems of Management in the 21st Century, 10(1), 18-25. http://www.scientiasocialis.lt/pmc/?q=node/123

Maria, S., Pusriadi, T., \& Darma, D. C. (2020). Marketing intelligence: Benefits and implementation of its business. Problems of Management in the 21st Century, 15(2), 92-99. https://dx.doi.org/10.33225/ $\mathrm{pmc} / 20.15 .92$

Marrone, M., \& Finotto, V. (2020). Challenging goliath. Informal unionism and digital platforms in the food delivery sector. The case of rider union Bologna. Partecipazione e Conflitto, 12(3), 691-716. https://doi.org/10.1285/i20356609v12i3p691

Mursitama, T. N. (2020). Ekonomi politik internasional Covid-19 [The international political economy of Covid-19]. Opini. https://nasional.sindonews.com/berita/1580944/18/ekonomi-politikinternasional-covid-19

Rusiadi, R., Aprilia, A., Adianti, V., \& Verawati, V. (2020). Dampak Covid-19 terhadap stabilitas ekonomi dunia (studi 14 Negara berdampak paling parah) [The impact of Covid-19 on world economic stability (study of 14 countries had the worst impact)]. Jurnal Kajian Ekonomi dan Kebijakan Publik, 5(2), 174-182.

Saubani, A. (2020). Empat sektor ekonomi yang paling tertekan pandemi Covid-19 [The four economic sectors that have been most hit by the Covid-19 pandemic]. Nasional. https://republika.co.id/ berita/q83llp409/empat-sektor-ekonomi-yang-paling-tertekan-pandemi-covid19

Supriyanto, B. (2020). Dampak pandemi Covid-19, ekonomi Indonesia diperkirakan pulih 2022 [The impact of the Covid-19 pandemic, the Indonesian economy is estimated to recover in 2022]. Ekonomi \& Bisnis. https://ekonomi.bisnis.com/read/20200427/9/1233454/dampak-pandemicovid-19-ekonomi-indonesia-diperkirakan-pulih-2022

The Food and Agriculture Organization. (2020). World food situation. The FAO Food Price Index drops to a seventeen-month low. http://www.fao.org/worldfoodsituation/foodpricesindex/en/

The International Monetary Fund. (2020). World economic outlook: the great lockdown. IMF.

The World Health Organization. (2020). Coronavirus disease (Covid-19) advice for the public. Emergencies. https://www.who.int/emergencies/diseases/novel-coronavirus-2019/advice-forpublic

The World Trade Organization. (2020). Covid-19: Measures affecting trade in goods. Covid-19 and world trade.https://www.wto.org/english/tratop_e/covid19_e/trade_related_goods_measure_e.htm 
Jiuhardi JIUHARDI, Dio CAISAR DARMA, Ariesta HEKSARINI. The political-economy management: Indonesia's needs for the Covid-19 pandemic

Received: March 20, 2021

Accepted: May 25, 2021

PROBLEMS

OF MANAGEMENT

IN THE $21^{\text {st }}$ CENTURY

Vol. 16, No. 1, 2021

27

Cite as: Jiuhardi, J., Caisar Darma, D., \& Heksarini, A. (2021). The political-economy management: Indonesia's needs for the covid-19 pandemic. Problems of Management in the $21^{\text {st }}$ Century, 16(1), 19-27. https://doi.org/10.33225/pmc/21.16.19

\begin{tabular}{|ll|}
\hline Jiuhardi Jiuhardi & $\begin{array}{l}\text { PhD, Associate Professor, Department of Economics, Faculty of Economics and } \\
\text { Business, Mulawarman University, Samarinda City, 75117, Indonesia. } \\
\text { E-mail: jiuhardi@feb.unmul.ac.id } \\
\text { Website: https://sinta.ristekbrin.go.id/authors/detail?id=6673739\&view=overview }\end{array}$ \\
& MSc, Researcher, Department of Management, Samarinda High College of \\
Dio Caisar Darma & Economics, Samarinda City, 75242, Indonesia. \\
(Corresponding author) & E-mail: diocaisar@stiesam.ac.id \\
& Website: https://sinta.ristekbrin.go.id/authors/detail?id=6680898\&view=overview \\
& ORCID: https://orcid.org/0000-0002-3287-7670 \\
& PhD, Senior Lecturer, Department of Management, Faculty of Economics and \\
Ariesta Heksarini & Business, Mulawarman University, Samarinda City, 75117, Indonesia. \\
& E-mail: ariesta.heksarini@feb.unmul.ac.id \\
& Website: https://sinta.ristekbrin.go.id/authors/detail?id=6157952\&view=overview \\
& ORCID: https://orcid.org/0000-0002-1844-9805
\end{tabular}

